\title{
Evaluation of Flexural Performance According to the Plywood Bonding Method of Ply-Lam CLT ${ }^{1}$
}

\author{
Gyu Woong $\mathrm{CHOI}^{2} \cdot$ Seung Min $\mathrm{YANG}^{2} \cdot \mathrm{Hyun}$ Jae $\mathrm{LEE}^{2}$ • \\ Jun Ho $\mathrm{KIM}^{2} \cdot$ Kwang Hyeon $\mathrm{CHOI}^{3} \cdot$ Seog Goo KANG ${ }^{2, \dagger}$
}

\begin{abstract}
The purpose of this study is to optimize the bonding method of the plywood suitable for cross-laminated timber (CLT) with plywood as a core by analyzing the flexural performance and failure mode according to the lamina species, the method of bonding plywood in the longitudinal direction, and whether or not adhesive is applied to the joint. In the case of the Douglas fir lamina layer, the modulus of elasticity decreased by about $11.5 \%$ due to longitudinal bonding, and the modulus of rupture increased or decreased according to the adhesive application and bonding method. The optimal conditions were derived as the butt joint without adhesive, half lap joint with adhesive, and butt joint. In the case of the larch lamina layer, the modulus of rupture and the modulus of elasticity decreased by about $15 \%$ and $40 \%$, respectively. When using the half lab joint and tongue \& groove joint, it is believed that it reduces the load transmitted to the middle layer by primarily preventing the failure on flexure at the joint of the plywood layer. From the results of this study, the larch lamina layer used in the manufacturing process of Ply-lam CLT did not show any difference based on the bonding method. Butt joint and half lap joint bonding method are determined to be suitable when using Douglas fir lamina layer.
\end{abstract}

Keywords: ply-lam clt, clt, plywood, end joint

\section{INTRODUCTION}

Global warming phenomena such as abnormally high temperatures and rising water temperature are continuing around the world. This phenomenon is a result of the emission of GHG (greenhouse gases) such as carbon dioxide, methane and nitrous oxide. There is a growing interest in reducing GHG emissions (Jung et al., 2019; Shim et al., 2019). Accordingly, measures are being discussed in all areas such as con- struction and transportation to reduce GHG emissions. Among them, at the $17^{\text {th }}$ Climate Change Conference in 2011, the effect of reducing GHG by carbon storage of wood products was recognized. Accordingly, interest in the use of wood with GHG absorption and carbon storage effect is increasing (Kim et al., 2019; Chung, 2019; Kim, 2019).

In addition, as GHG reduction becomes mandatory after 2020, interest in wooden buildings around the world has increased, and construction cases of

\footnotetext{
${ }^{1}$ Date Received July 28, 2020, Date Accepted January 14, 2021

${ }^{2}$ Department of Bio-based materials, Chungnam National University, Deajeon 34134, Republic of Korea

${ }^{3}$ Huin co., Ltd. Gwangju 62235, Republic of Korea

$\dagger$ Corresponding author: Seog Goo KANG (e-mail: lachesis@cnu.ac.kr, ORCID: 0000-0002-2440-7070)
} 
Gyu Woong CHOI $\cdot$ Seung Min YANG $\cdot$ Hyun Jae LEE $\cdot$ Jun Ho KIM $\cdot$ Kwang Hyeon CHOI $\cdot$ Seog Goo KANG

high-rise wooden buildings are increasing. Wooden construction has been in the spotlight as a sustainable construction technology as it not only reduces energy consumption and GHG, but also uses wood as a major building material in the long term (Yoo et al., 2019).

Accordingly, not only interest in wood is increasing but also in recent European countries, large-sized wood panel CLT (Cross Laminated Timber) has been developed and used to compensate for fireproofing, soundproofing, and thermal storage functions, etc., which are weaknesses of lightweight wooden structures. When CLT is applied as a building member, the construction period is shortened and the insulation performance and airtightness are improved through the precast modular construction method. This also has the advantage that it can be used as a high-rise wooden building material, so construction cases of high-rise wooden buildings are increasing (Hassanieh et al., 2017; Chang et al., 2018). Construction examples include an 18-floor wooden structure at the University of British Columbia in Vancouver, Canada in 2017, a 9-floor Stadthaus in London, UK in 2009, and a 10-floor Forte wooden structure in Melbourne, Australia in 2012. In London, UK, a bird's-eye view of "Oakwood", a super-high-rise wooden building, was disclosed, and high-rise buildings using wood are gradually increasing (Kim et al., 2019; Kim, 2019).

As such, CLT used in high-rise wooden buildings is engineered wood in which the lamina layer is stacked orthogonally in the direction of the wood. It is used in regions such as Europe, the United States, and Canada. Recently, among the wood materials to which the composition of CLT is applied, a study on the development and performance of a composite CLT in which laminated veneer lumber (LVL), plywood, and bamboo board are mixed and laminated is in progress (Park et al., 2017; Choi et al., 2015; Choi et al., 2018; Nurdiansyah et al., 2020; Barreto et al., 2019; Wang et al., 2017). In Korea, studies are being con- ducted on the material properties of CLT using small hardwood and CLT using flame retardant materials, shear walls, joints, and housing performance (heat insulation, sound absorption) of CLT (Jang et al., 2019; Pang et al., 2017; Choi et al., 2018; Oh et al., 2017; Kang et al., 2019; Jung et al., 2020).

In addition to active research on CLT, domestic CLT production facilities are being introduced. CLT is being produced by using domestic larch lamina layer and Ply-lam CLT with plywood mixed and laminated to improve yield (Pang et al., 2019; Choi et al., 2020). In particular, domestically produced larch plywood is used for Ply-lam CLT, and it is easy to manufacture Ply-lam CLT with a length of $2,440 \mathrm{~mm}$ according to the plywood standard. For CLT, a large-sized wooden panel, the length of a 120 mm-thick modulus of rupture test piece is approximately $3,600 \mathrm{~mm}$ or more, which is $25-30$ times the thickness (ANSI/APA, 2018). However, Ply-lam CLT, in which plywood is mixed and laminated, is required to join the longitudinal direction of plywood when manufacturing panels with the length longer than 2,440mm.

In this study, a plywood bonding method suitable for Ply-lam CLT is derived by analyzing the flexural performance and failure mode according to the lamina layer species, the method of bonding plywood in the longitudinal direction, and whether or not adhesive is applied to the joint.

\section{MATERIALS and METHODS}

\subsection{Materials}

\subsubsection{Larch plywood}

The plywood used to manufacture Ply-lam CLT was used by pre-sale of $15 \mathrm{~mm}$ structural larch plywood manufactured by $\mathrm{S}$ company located in Incheon, using larch (Larix kaempferi (Lamb.) Carrière). The physical 
Table 1. Structural larch plywood properties

\begin{tabular}{c|c|c|c|c|c|c|c}
\hline \multirow{2}{*}{$\begin{array}{c}\text { Oven-dry density } \\
\text { (unit: } \mathrm{g} / \mathrm{cm}^{3} \text { ) }\end{array}$} & $\begin{array}{c}\text { Moisture content } \\
\text { (unit: \%) }\end{array}$ & $\begin{array}{c}\text { Modulus of rupture in } \\
\text { bending } \\
\text { (unit: } \mathrm{MPa})\end{array}$ & $\begin{array}{c}\text { Modulus of elasticity in } \\
\text { bending } \\
\text { (unit: GPa) }\end{array}$ & \multicolumn{2}{|c}{$\begin{array}{c}\text { Bonding } \\
\text { Strength }\end{array}$} & $\begin{array}{c}\text { Emission Class } \\
\text { of Formaldehyde }\end{array}$ \\
\cline { 3 - 6 } $0.5 \pm 0.02$ & $8.9 \pm 0.5 \%$ & $42.8 \pm 11.8$ & $28.7 \pm 5$ & $7.1 \pm 2.1$ & $4.0 \pm 0.3$ & $\begin{array}{c}\text { Highly water } \\
\text { resistant } \\
\text { (Type 1) }\end{array}$ & $\mathrm{E}_{0}$ \\
\hline \hline
\end{tabular}

properties of the used structural larch plywood are shown in Table 1. The larch plywood with a thickness of $15 \mathrm{~mm}$, which passed the first grade of KS F 3113 structural plywood standards, was used.

\subsubsection{Lamina layers}

The lamina layers used in the Ply-lam CLT were Douglas fir (Pseudotsuga menziesii (Mirb.) Franco, oven-dry specific gravity 0.52 ) and larch (Larix kaempferi (Lamb., total weight 0.54) Carrière). Two species of lamina layers were used as the testing materials. Douglas fir lamina layers were classified into mechanical grades E12-13 (MOE: 12-14 GPa) and E9 (MOE: 9-10 GPa) lamina layers. E12-13 (MOE: 12-14 GPa) grade was used as the outermost layer, and the E9 (MOE: 9-10 GPa) grade was used as the intermediate layer. The larch lamina layer was used as a mechanical grade E11 and E9 layers, and the layer composition of Ply-lam CLT was the same as that of Douglas fir. The Douglas fir used was a knotless lamina layer and it was used cut into $15 \mathrm{~mm}$ thick, $100 \mathrm{~mm}$ wide, and 2,400 $\mathrm{mm}$ long. Larch was a knotless lamina layer and was manufactured and used in a thickness of $15 \mathrm{~mm}$, a width of $100 \mathrm{~mm}$, and a length of 2,400 $\mathrm{mm}$ through a longitudinal finger joint method.

\subsubsection{Manufacturing Ply-lam CLT}

In this study, a plywood bonding method suitable for Ply-lam CLT was derived by analyzing the flexural performance and failure pattern according to the longitudinal plywood bonding method, and whether or not

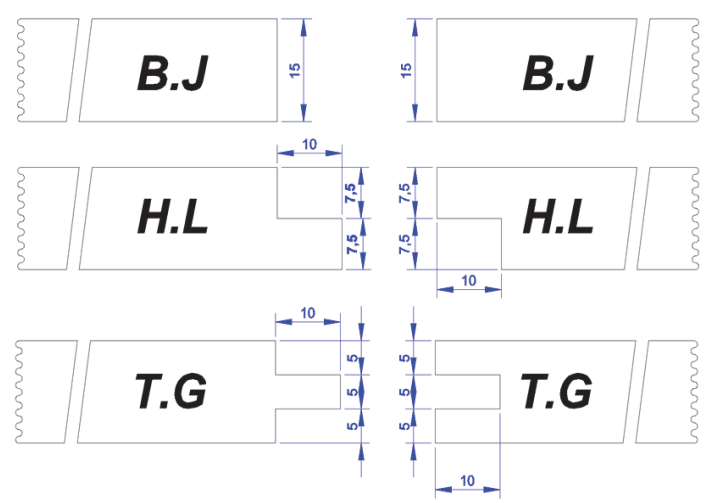

Fig. 1. Three types(T.G, H.L, B.J) of plywood longitudinal joint.

an adhesive is applied. For this purpose, three types of Ply-lam CLT were prepared according to the notreatment conditions without plywood bonding and the longitudinal bonding method. As for the longitudinal bonding method of plywood, three bonding methods were selected: Butt Joint (hereinafter referred to as B.J), Half Lap Joint (hereinafter referred to as H.L), and Tongue \& Groove Joint (hereinafter referred to as T.G), which are most commonly used for bonding wood in the longitudinal direction. Fig. 1 shows the processing drawing of the plywood according to the bonding method.

In order to compare the flexural characteristics of the plywood by the bonding method, Ply-lam CLT was manufactured by arranging the joint in the longitudinal direction of the plywood to be located in the center of the modulus of rupture test specimen.

Room temperature hardening type phenol-resorcinol resin was used as an adhesive for manufacturing Ply-lam 
Gyu Woong CHOI $\cdot$ Seung Min YANG $\cdot$ Hyun Jae LEE $\cdot$ Jun Ho KIM $\cdot$ Kwang Hyeon CHOI $\cdot$ Seog Goo KANG

Table 2. Ply-lam CLT specimen according to plywood longitudinal joint method

\begin{tabular}{|c|c|c|c|c|c|}
\hline Species & $\begin{array}{l}\text { Machine stress } \\
\text { grade of lamina }\end{array}$ & Joint method & Adhesive & Repetition & Specimen size $(\mathrm{mm})$ \\
\hline \multirow{7}{*}{$\begin{array}{c}\text { Pseudotsuga } \\
\text { menziesii(Mirb.) Franco }\end{array}$} & \multirow{7}{*}{ E12-13 } & Control & $x$ & \multirow{14}{*}{5} & \multirow{14}{*}{$75(\mathrm{~T}) \times 300(\mathrm{~W}) \times 2,400(\mathrm{~L})$} \\
\hline & & \multirow{2}{*}{ Butt joint } & o & & \\
\hline & & & $x$ & & \\
\hline & & \multirow{2}{*}{ Half Lap joint } & ० & & \\
\hline & & & $\times$ & & \\
\hline & & \multirow{2}{*}{ Tongue \& Groove joint } & 0 & & \\
\hline & & & $x$ & & \\
\hline \multirow{7}{*}{$\begin{array}{c}\text { Larix kaempferi (Lamb.) } \\
\text { Carriere }\end{array}$} & \multirow{7}{*}{ E11 } & Control & $\times$ & & \\
\hline & & \multirow{2}{*}{ Butt joint } & o & & \\
\hline & & & $x$ & & \\
\hline & & \multirow{2}{*}{ Half Lap joint } & ० & & \\
\hline & & & $x$ & & \\
\hline & & \multirow{2}{*}{ Tongue \& Groove joint } & 0 & & \\
\hline & & & $x$ & & \\
\hline
\end{tabular}

CLT, and the main material (phenol-resorcinol resin) and a curing agent (paraformaldehyde) were mixed with a ratio of 100:30 and used. At this point, the Ply-lam CLT (lamina layer-plywood-lamina layer-plywood-lamina layer) having a thickness of $75 \mathrm{~mm} \mathrm{(5}$ ply) was prepared after cold-pressing for 24 hours under a pressure condition of $10 \mathrm{kgf} / \mathrm{cm}^{2}$ and curing for 7 days after applying adhesive based on $150 \mathrm{~g} / \mathrm{m}^{2}$ of single-sided coating amount. The Ply-lam CLT manufactured for each condition was cut according to APA PRG 320 Standard for Performance-Rated Cross- Laminated Timber and ASTM D 198-15 Standard Test Methods of Static Tests of Lumber in Structural Sizes to be used as test pieces. The manufacturing conditions and the test specimen size of Ply-lam CLT is shown in Table 2.

\subsection{Experiment method}

\subsubsection{Evaluation of the flexural performance and failure mode of Ply-lam CLT according to the plywood bonding method}

The prepared flexural performance test piece $(75 \mathrm{~mm}$
$(\mathrm{T}) \times 305 \mathrm{~mm}(\mathrm{~W}) \times 2,400 \mathrm{~mm}(\mathrm{~L}))$ was tested by Two-Point Loading method among ASTM D 198-15 flexural performance evaluation methods using a universal testing machine (KDPI-130-1). At this point, the span of the test piece was $2,175 \mathrm{~mm}$ (29 times the thickness) and the load speed was set to reach the maximum load within about 300 seconds. Modulus of rupture, the deflection and load measured with the maximum load at the center of the specimen were used to calculate the Modulus of Elasticity according to Equations (1) and (2).

$$
\text { Modulus of Rupture }(M P a)=\frac{3 P_{\max } a}{b d^{2}}
$$

$P_{\max }$ : maximum load borne by specimen loaded $(N)$

$a$ : distance from reaction to nearest load point $(\mathrm{mm})$

$b$ : width of specimen $(\mathrm{mm})$

$d$ : depth of specimen ( $\mathrm{mm}$ )

Modulus of Elasticity $(G P a)=\frac{P a}{4 b d^{3} \triangle}\left(3 l^{2}-4 a^{2}\right)$

$P$ : increment of applied load on flexure specimen below proportional limit $(N)$ 
a: distance from reaction to nearest load point ( $\mathrm{mm})$

$b$ : width of specimen $(\mathrm{mm})$

$d$ : depth of specimen $(\mathrm{mm})$

$l$ : span of beam (mm)

$\triangle$ : increment of deflection of neutral axis of flexure specimen measured at midspan over distance and corresponding load (mm)

One-way ANOVA was performed on the calculated results using SPSS (ver. 24.0, SPSS Inc., USA), and the significance of the mean value $(\mathrm{P}<0.05)$ was tested by Duncan's multiple range test.

\section{RESULTS and DISCUSSION}

\subsection{Comparison of flexural performance of Ply-lam CLT according to the lamina species}

\subsubsection{Ply-lam CLT using Douglas fir lamina layer}

The results of the flexural performance of Ply-lam CLT using the Douglas fir lamina layer is shown in
Fig. 2. Depending on whether the longitudinal adhesive was applied or not, the same level of strength value was shown for the condition (without longitudinal joint) and the butt joint. When the adhesive was not applied based on the average value, the modulus of rupture decreased by about $10 \%$ in the half lap, tongue $\&$ groove. When the adhesive was applied, the modulus of rupture decreased by about $7 \%$ in the tongue $\&$ groove. Regardless of whether the adhesive was applied or not, the modulus of elasticity was reduced by about $11.5 \%$ due to the longitudinal bonding method.

The average significance of the modulus of rupture and modulus of elasticity of the plywood of no-treatment condition without longitudinal bonding and the three longitudinal bonding methods was verified (Table 3). When the adhesive was not applied, there was no significant difference between the results of modulus of rupture based on the condition (without

Fig. 2. Flexural performance result of Ply-lam CLT using douglas fir lamina.

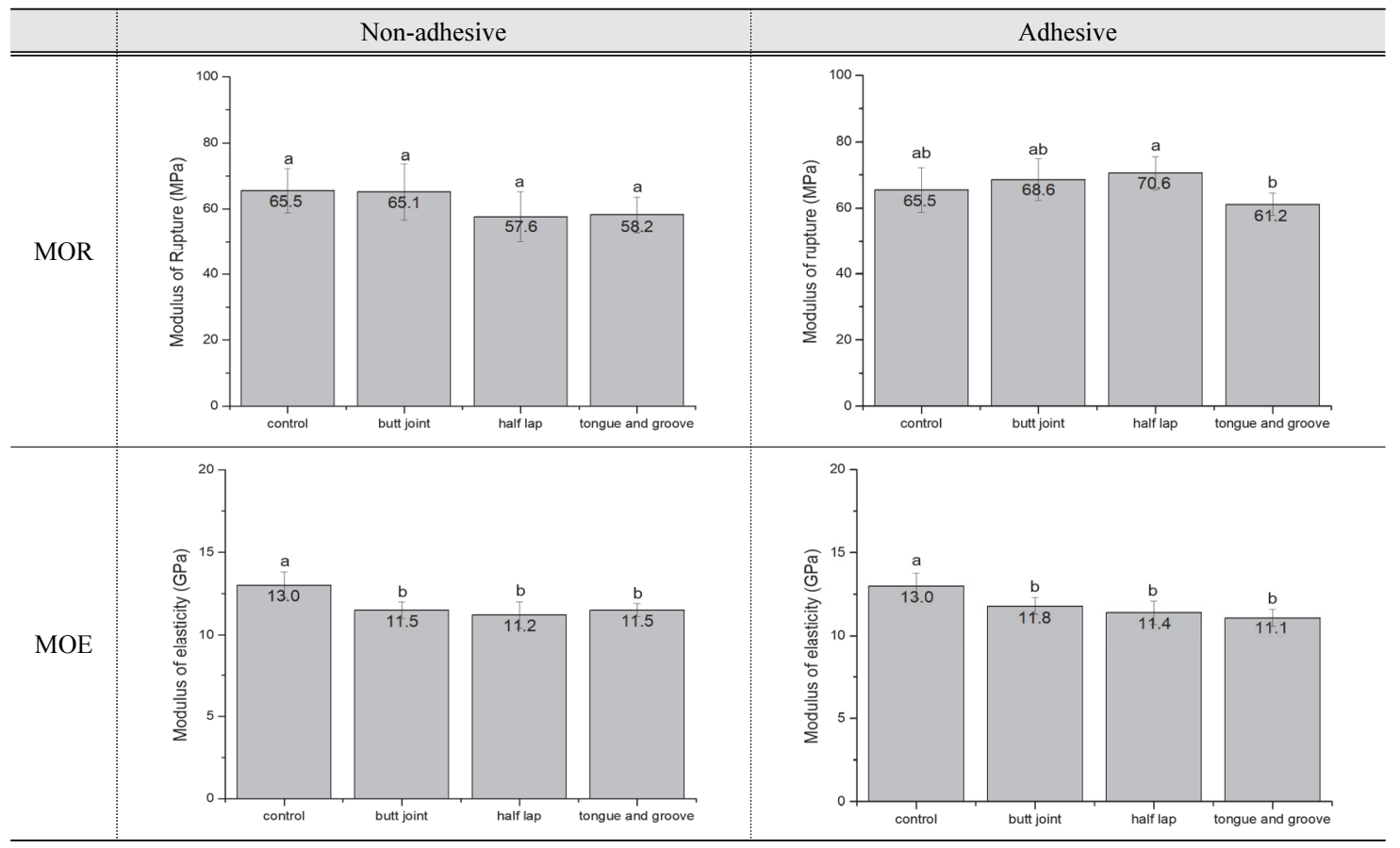


Gyu Woong CHOI $\cdot$ Seung Min YANG $\cdot$ Hyun Jae LEE $\cdot$ Jun Ho KIM $\cdot$ Kwang Hyeon CHOI $\cdot$ Seog Goo KANG

Table 3. Flexural performance significance verification result of Ply-lam CLT using douglas fir lamina

\begin{tabular}{|c|c|c|c|c|c|}
\hline & Flexural performance & Plywood joint method & Average & Standard deviation & F-value \\
\hline \multirow{8}{*}{ Non-adhesive } & \multirow{4}{*}{$\begin{array}{c}\text { MOR } \\
\text { (unit: } \mathrm{MPa} \text { ) }\end{array}$} & Control & 65.5 & 6.7 & \multirow{4}{*}{$\begin{array}{c}1.434 \\
(1.315)\end{array}$} \\
\hline & & Butt joint & 65.1 & 8.6 & \\
\hline & & Half Lap joint & 57.6 & 7.5 & \\
\hline & & Tongue \& Groove joint & 58.2 & 5.3 & \\
\hline & \multirow{4}{*}{$\begin{array}{c}\text { MOE } \\
\text { (unit: GPa) }\end{array}$} & Control & 13.0 & 0.8 & \multirow{4}{*}{$\begin{array}{l}6.828^{*} \\
(0.403)\end{array}$} \\
\hline & & Butt joint & 11.5 & 0.5 & \\
\hline & & Half Lap joint & 11.2 & 0.8 & \\
\hline & & Tongue \& Groove joint & 11.5 & 0.4 & \\
\hline \multirow{8}{*}{ Adhesive } & \multirow{4}{*}{$\begin{array}{c}\text { MOR } \\
\text { (unit: } \mathrm{MPa} \text { ) }\end{array}$} & Control & 65.5 & 6.7 & \multirow{4}{*}{$\begin{array}{c}2.186 \\
(3.807)\end{array}$} \\
\hline & & Butt joint & 68.6 & 6.3 & \\
\hline & & Half Lap joint & 70.6 & 5 & \\
\hline & & Tongue \& Groove joint & 61.2 & 3.4 & \\
\hline & \multirow{4}{*}{$\begin{array}{c}\text { MOE } \\
\text { (unit: GPa) }\end{array}$} & Control & 13.0 & 0.8 & \multirow{4}{*}{$\begin{array}{l}7.405^{* *} \\
(1.466)\end{array}$} \\
\hline & & Butt joint & 11.8 & 0.5 & \\
\hline & & Half Lap joint & 11.4 & 0.7 & \\
\hline & & Tongue \& Groove joint & 11.1 & 0.5 & \\
\hline
\end{tabular}

- ( ) vale: F-value result according to the plywood joint method excluding control

- *: $\mathrm{p}<0.05, * *: \mathrm{p}<0.01, * * *: \mathrm{p}<0.001$

Table 4. Flexural performance significance verification result of Ply-lam CLT using larch lamina

\begin{tabular}{|c|c|c|c|c|c|}
\hline & Flexural performance & Plywood joint method & Average & Standard deviation & F-value \\
\hline \multirow{8}{*}{ Non-adhesive } & \multirow{4}{*}{$\begin{array}{c}\text { MOR } \\
\text { (unit: } \mathrm{MPa} \text { ) }\end{array}$} & Control & 61.6 & 8.5 & \multirow{4}{*}{$\begin{array}{l}4.569^{*} \\
(0.058)\end{array}$} \\
\hline & & Butt joint & 52.4 & 2 & \\
\hline & & Half Lap joint & 52.1 & 0.2 & \\
\hline & & Tongue \& Groove joint & 52.2 & 0.5 & \\
\hline & \multirow{4}{*}{$\begin{array}{c}\text { MOE } \\
\text { (unit: GPa) }\end{array}$} & Control & 15.1 & 0.6 & \multirow{4}{*}{$\begin{array}{c}127.6 * * * \\
(0.086)\end{array}$} \\
\hline & & Butt joint & 9.1 & 0.7 & \\
\hline & & Half Lap joint & 9.0 & 0.5 & \\
\hline & & Tongue \& Groove joint & 9.2 & 0.2 & \\
\hline \multirow{8}{*}{ Adhesive } & \multirow{4}{*}{$\begin{array}{c}\text { MOR } \\
\text { (unit: } \mathrm{MPa} \text { ) }\end{array}$} & Control & 61.6 & 8.5 & \multirow{4}{*}{$\begin{array}{l}4.507^{*} \\
(0.059)\end{array}$} \\
\hline & & Butt joint & 52.5 & 2.1 & \\
\hline & & Half Lap joint & 52.1 & 0.2 & \\
\hline & & Tongue \& Groove joint & 52.2 & 0.5 & \\
\hline & \multirow{4}{*}{$\begin{array}{c}\text { MOE } \\
\text { (unit: GPa) }\end{array}$} & Control & 15.1 & 0.6 & \multirow{4}{*}{$\begin{array}{c}179.707 * * * \\
(0.997)\end{array}$} \\
\hline & & Butt joint & 9.3 & 0.5 & \\
\hline & & Half Lap joint & 9.1 & 0.2 & \\
\hline & & Tongue \& Groove joint & 9.3 & 0.4 & \\
\hline
\end{tabular}

- ( ) vale: F-value result according to the plywood joint method excluding control

- *: $\mathrm{p}<0.05, * *: \mathrm{p}<0.01, * * *: \mathrm{p}<0.001$ 
longitudinal joint) and the bonding method. However, there was a significant difference in the condition where the adhesive was applied.

Moreover, the modulus of rupture $(\mathrm{F}=2993, \mathrm{p}=0.031)$ showed a significant difference based on whether the adhesive was applied or not, and the adhesive application condition showed a higher level of strength. However, the modulus of elasticity $(\mathrm{F}=0.739, \mathrm{p}=0.602)$ did not show a significant difference based on whether the adhesive was applied or not. The half lap joint bonding method showed the highest modulus of rupture performance when the adhesive was applied, and the butt joint showed the highest modulus of rupture performance when the adhesive was not applied.

\subsubsection{Ply-lam CLT using larch lamina layer}

The flexural performance results of Ply-lam CLT using larch lamina layer and larch plywood is shown in Fig. 3.
A significant difference was found as a result of verifying the average significance of the modulus of rupture and modulus of elasticity of conditions without longitudinal bonding of plywood and 3 types of longitudinal bonding methods. Based on the longitudinal bonding, the modulus of rupture decreased by about $15 \%$ and the modulus of elasticity decreased by about $40 \%$.

As a result of verifying the significance of modulus of rupture and modulus of elasticity according to the bonding method, there was no significant difference according to the bonding method. In addition, the modulus of rupture $(\mathrm{F}=0.059, \mathrm{p}=0.997)$ and the modulus of elasticity $(\mathrm{F}=0.364, \mathrm{p}=0.868)$ were not significantly different depending on whether the adhesive was applied or not.

\subsection{Flexural failure mode based on whether the adhesive is applied or not}

In the condition without longitudinal joint, failure starts

Fig. 3. Flexural performance result of Ply-lam CLT using larch lamina.

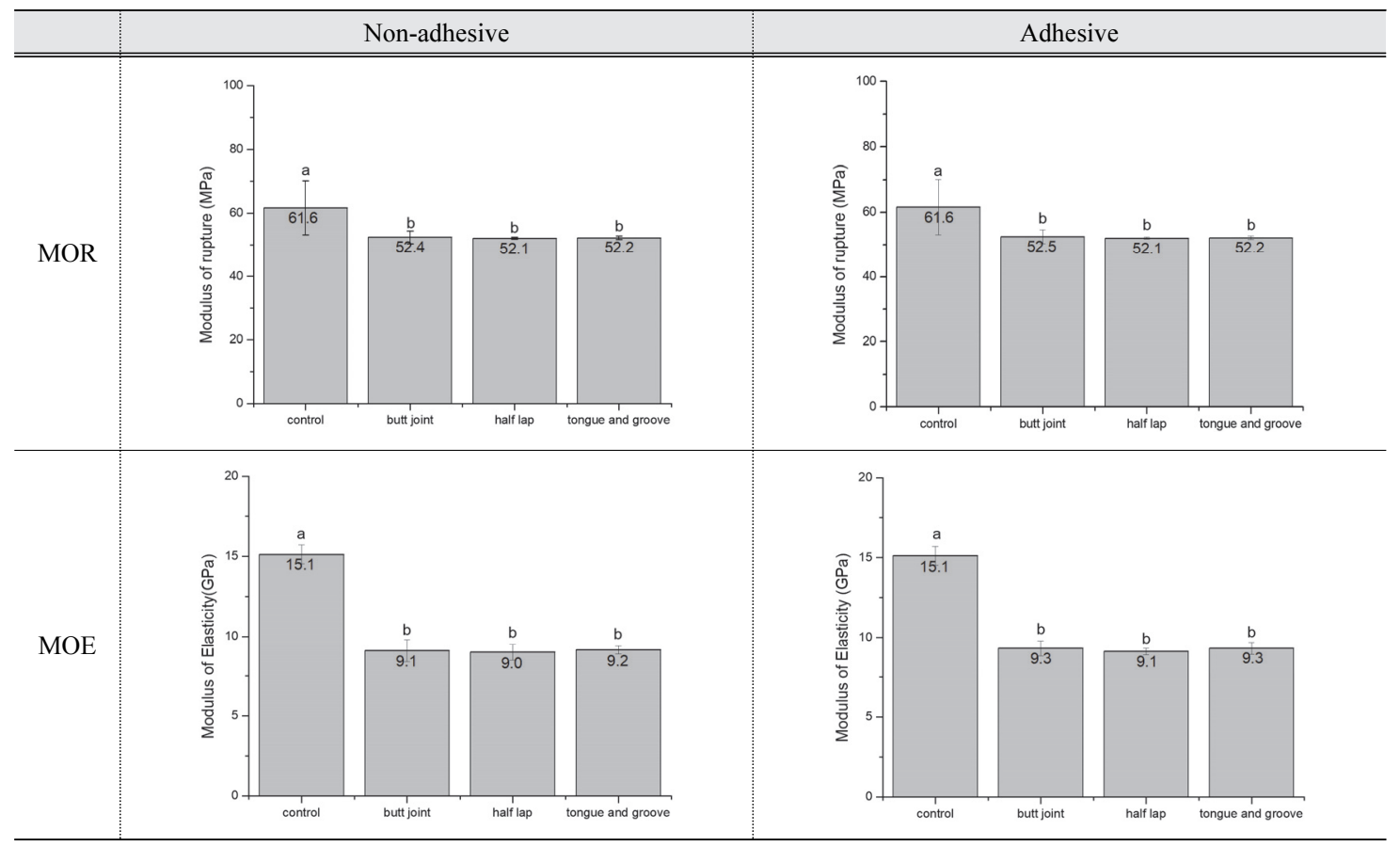


Gyu Woong CHOI $\cdot$ Seung Min YANG $\cdot$ Hyun Jae LEE $\cdot$ Jun Ho KIM $\cdot$ Kwang Hyeon CHOI $\cdot$ Seog Goo KANG

Table 5. Flexure Failure mode of longitudinal plywood joints using adhesives

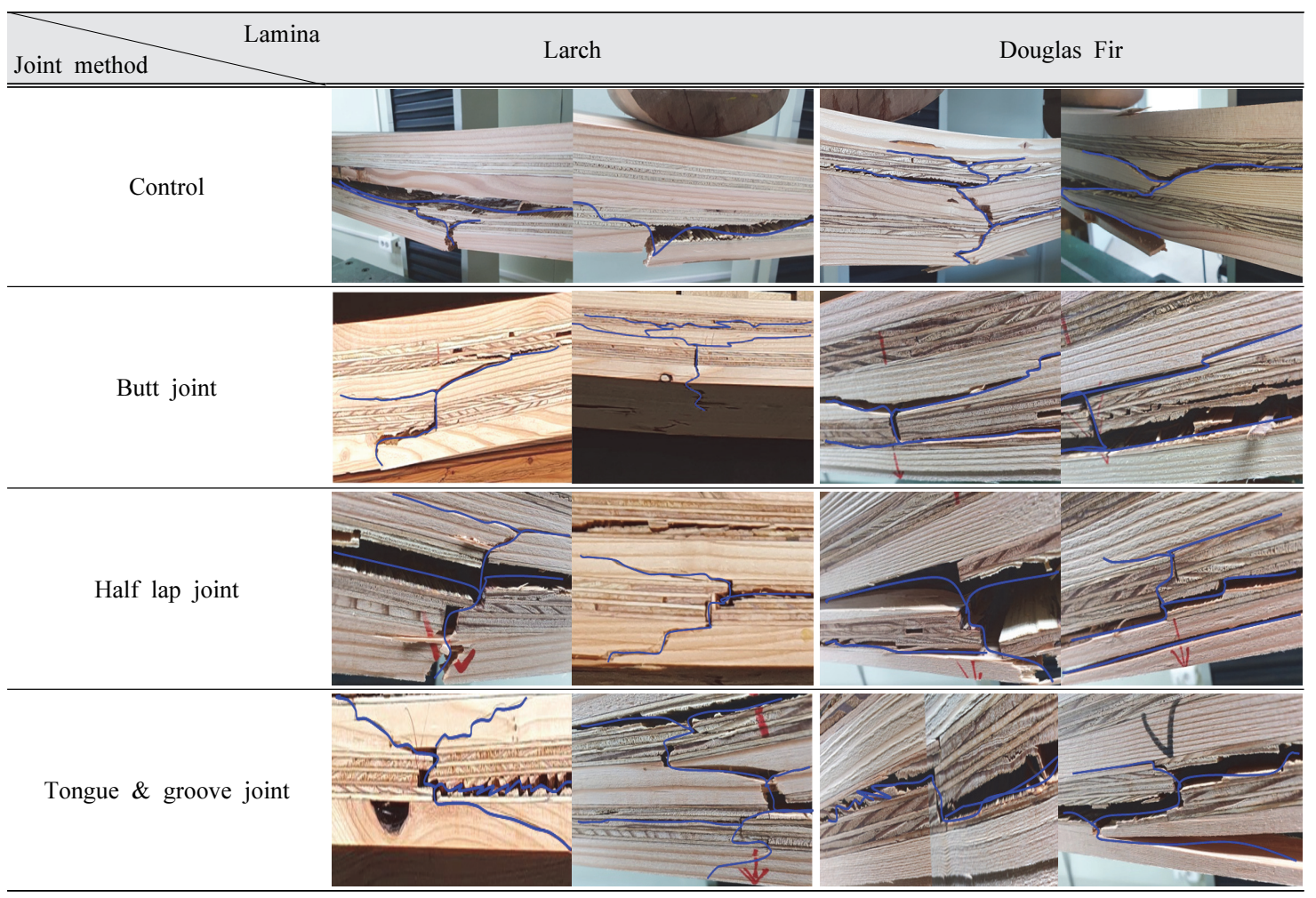

Table 6. Flexure Failure mode of longitudinal plywood joints(non-adhesive)

Joint method Lamina Larch


from defects such as knots at maximum load, and failure occurs for each layer of 2 ply plywood veneer. On the other hand, when the adhesive is applied to the plywood joint, unlike other joint methods, it was found that a failure of the butt joint passes through the plywood joint of the middle layer when the outermost lamina layer is destroyed, and transmitted directly to the lamina layer of the core (Table 5). However, in the half lap joint, tongue \& groove joint, the failure was not transmitted from the middle layer plywood directly to the lamina layer of the core part, and the failure occurred first in the plywood. As a result, it was determined that the failure to the core part was mitigated from being transmitted immediately. In the case of using a radiator pine lamina layer, the effect of strength improvement was shown at the half lap joint and butt joint coated with the adhesive, but the modulus of rupture was not improved because the plywood was first destroyed in the tongue $\&$ groove joint.

It was analyzed that the failure pattern of the case of not applying the adhesive showed the same result with the case of applying the adhesive (Table 6).

\section{CONCLUSION}

In this study, to evaluate the flexural performance based on the plywood bonding method of Ply-lam CLT, the strength performance based on the application of the adhesive between 2 types of lamina layers, 3 types of plywood bonding methods, and interlayer plywood bonding was compared and analyzed, and the following results were derived.

1. In the case of the Douglas fir layer, the modulus of elasticity decreased by about $11.5 \%$ compared to the condition without plywood joint, and the modulus of rupture increased or decreased depending on the adhesive application and bonding method. The optimal conditions were derived as the butt joint without adhesive, half lap joint with adhesive, and butt joint.

2. In the case of the larch lamina layer, the modulus of rupture decreased by about $15 \%$ and the modulus of elasticity by about $40 \%$ due to the longitudinal bonding. There was no difference based on the bonding method.

3. When using the half lab joint and tongue \& groove joint, it is decided that it reduces the load transmitted to the middle layer by primarily preventing the failure on flexure at the joint of the plywood layer.

4. From the results of this study, the larch lamina layer used in the manufacturing process of Ply-lam CLT did not show any difference based on the bonding method. Butt joint and half lap joint method are determined to be suitable when using Douglas fir lamina layer.

\section{ACKNOWLEDGMENT}

This study was carried out with the support of 'R\&D Program for Forest Science Technology (Project No. 2020161C10-2020-AD01)' provided by Korea Forest Service(Korea Forestry Promotion Institute).

\section{REFERENCES}

ANSI/APA. 2018. PRG 320 Standard for PerformanceRated Cross-Laminated Timber. APA-The engineered Wood Association, Tacoma, WA.

ASTM D 198-15 Standard Test Method of Static Tests of Lumber in Structural Sizes. 2015. ASTM international.

Barreto, M.I.M., Araujo, V.D., Barbosa, J.C., Christofore, A.L., Moura, J.D.M. 2019. Structure Performance nalysis of Cross-Laminated Timber-Bamboo(CLTB). BioResources 14(3): 545-5058.

Chang, S.J., Yoo, J.W., Kang, S.G., Kim, S.M. 2018. 
Gyu Woong CHOI $\cdot$ Seung Min YANG $\cdot$ Hyun Jae LEE $\cdot$ Jun Ho KIM $\cdot$ Kwang Hyeon CHOI $\cdot$ Seog Goo KANG

Evaluation of the Building Energy Demands of the CLT Wooden Houses according to the Korean Climatic Condition. Journal of The Korean Society of Living Environmental System 25(6): 671-678. Choi, C., Yuk, C.R., Yoo, J.C., Park, J.Y., Lee, C.G., Kang, S.G. 2015. Physical and Mechanical Properties of Cross Laminated Timber Using Plywood as Core Layer. Journal of the Korean Wood Science and Technology 43(1): 86-95.

Choi, C., Erina, K., Kim, K.J., Yamasaki, M., Sasaki, Y., Kang, S.G. 2018. Analysis of Mechanical Properties of Cross-laminated Timber(CLT) with Plywood using Korean Larch. BioResources 13(2): 2715-2726.

Choi, G.W., Yang, S.M., Lee, H.J., Kim, J.H., Chio, K.H., Kang, S.G. 2020. A Study on the Block Shear Strength according to the Layer Composition of and Adhesive Type of Ply-Lam CLT. Journal of the Korean Wood Science and Technology 48(6): 791-806.

Choi, Y.S., Park, J.W., Lee, J.H., Shin, J.H., Jang, S.W., Kim, H.J. 2018. Preparation of EVA/Intumescent/ Nano-Clay Composite with Flame Retardant Properties of Cross Laminated Timber(CLT) Application Technology. Journal of the Korean Wood Science and Technology 46(1): 73-84.

Chung, W.Y. 2019. National Policies and Developmental Strategy of Furniture Industry of Korea Corresponding the Climate Change. Journal of the Korea furniture Society 30(2): 130-142.

Hassanieh, A., Valipour, H.R., Bradford, M.A. 2017. Experimental and numerical investigation of shortterm behaviour of CLT-steel composite beams, Engineering Structures 144: 43-57.

Jang, S.S., Lee, H.W. 2019. Lateral Resistance of CLT Wall Panels Composed of Square Timber Larch Core and Plywood Cross Bands. Journal of the Korean Wood Science and Technology 47(5): 547-556. Jung, J.H., Chio, Y.E., Moon, J.Y., Park, M.N. 2019.
Analysis on the Public Awareness of Weather Phenomena in the Context of Climate Change or Global Warming in the Republic of Korea Using Big Data. Journal of Climate Research 14(4): 245-258. Jung, H.J., Song, Y.J., Hong, S.I. 2020. Effect of Glass Fiber-Reinforced Connection on the Horizontal Shear Strength of CLT Walls. Journal of the Korean Wood Science and Technology 48(5): 685-695. Kang, C.W., Jang, S.S., Kang, H.Y., Li, C. 2019. Sound Absorption Rate and Sound Transmission Loss of CLT Wall Panels Composed of Larch Square Timber Core and Plywood Cross Band. Journal of the Korean Wood Science and Technology 47(1): 33-39.

Kim, K.H., Jeon, W.S. 2019. Evaluation of Bonding Performance of CLT Using Mixed Species with Polyurethane Adhesive. Journal of the Korea Furniture Society 30(4): 327-332.

Kim, M.J., Chang, Y.S., Kim, M.J., Shim, K.B., Eom, C.D. 2019. Assessment of Carbon Storage Capacity by Substitution of Wood in Public Facility: Comparative Analysis of Seoullo 7017. Journal of the Korea furniture Society 30(4): 312-318.

Kim, S.J. 2019. Timber Construction and Fire Resistance. Review of Architecture and Building Science 63(11): 41-44.

KS F 3113 Structural Plywood. 2016. Korean Industrial Standards.

Nurdiansyah, M.G., Yang, S.M., Yu, S.M., Kang, S.G. 2020. Study on the Mechanical Properties of Tropical Hybrid Cross Laminated Timber Using Bamboo Laminated Board as Core Layer. Journal of the Korean Wood Science and Technology 48(2): 245-252.

Oh, J.K., Kim, G.C., Kim, K.M., Lee, J.J., Hong, J.P. 2017. End Distance of Single-shear Screw Connection in Cross Laminated Timber. Journal of the Korean Wood Science and Technology 45(6): 746-752. Pang, S.J., Lee, B.J., Jeong, G.Y. 2017. Insulation 
Evaluation of flexural performance according to the plywood bonding method of Ply-lam CLT

Saving Effect for Korean Apartment House Using Cross-Laminated Timber(CLT). Journal of the Korean Wood Science and Technology 45(6): 846-856.

Pang, S.J., Lee, H.J., Yang, S.M.., Kang, S.G., Oh, J.K. 2019. Moment and shear capacity of Ply-lam composed with plywood and structural timber under out-of-plane bending. Journal of Wood Science 65(68): 1-10.

Park, S.H., Kim, K.M., Pang, S.J., Kong, J.H., Lee, S.J. 2017. Evaluation of Shear strength by Direction of Wood Grain for Korean Pine Using PRF Adhesive. Journal of the Korean Wood Science and Technology 45(3): 243-249.
Shim, S.B., Kwon, S.H., Lim, Y.J., Yum, S.S., Byun, Y.H. 2019. Understanding Climate Change over East Asia under Stabilized 1.5 and $2.0^{\circ} \mathrm{C}$ Global Warming Scenarios. Atmosphere. 29(4): 391-401. Wang, Z., Fu, H., Gong, M., Luo, M., Luo, J., Dong, W., Wang, T., Chui, Y.H. 2017. Planar shear and bending properties of hybrid CLT fabricated with lumber and LVL. Construction and Building Materials 151(1): 172-177.

Yoo, D.W., Lee, T.G. 2019. Analysis of Energy Performance and Structure of Wooden Passive Houses Using CLT in Overseas. KIEAE Journal 19(5): 101-107. 
Gyu Woong CHOI $\cdot$ Seung Min YANG $\cdot$ Hyun Jae LEE $\cdot$ Jun Ho KIM $\cdot$ Kwang Hyeon CHOI $\cdot$ Seog Goo KANG

\title{
APPENDIX
}

\author{
(Korean Version)
}

\section{Ply-lam CLT의 합판 접합방식에 따른 휨 성능 평가}

초록: 본 연구에서는 층재 수종과 길이방향의 합판 접합방식과 접합부의 접착제 도포 여부에 따른 휨 성능 및 파괴 양상 분석을 통하여 합판을 코어로 사용한 CLT에 적합한 합판의 접합 방식을 최적화 하고자 하였다. 더글라스 퍼 층재의 경우 길이방향 접합에 의해 휨탄성계수 약 $11.5 \%$ 감소, 휨강도는 접착제 도포 및 접합방식에 따라 증가 또는 감소하였다. 접착제 미도포 butt joint, 접착제 도포 half lap joint, butt joint 조건이 최적조건으로 도출 되었다. 낙엽송 층재의 경우 길이방향 접합에 의해 휨강도는 약 $15 \%$, 휨탄성계수는 약 $40 \%$ 감소하였으며 접합방식에 따른 차이를 나타내지 않았다. half lab joint와 tongue $\&$ groove joint 사용 시 합판 층의 접합부에서 휨에 파괴를 1 차적으로 방지해줌으로써 중층의 층재로 전달되는 하중을 감소시켜 주는 것으로 판단된다. 본 연구 결과를 통해 Ply-lam CLT 제조과정에서 낙엽송 층재를 사용하는 경우 접합방법에 따른 차이를 나타내지 않았으며 더글라스퍼 층재를 사용할 경우 butt joint와 half lap 접합 방식이 적합할 것으로 판단된다.

\section{1. 서 론}

전 세계적으로 이상고온현상 및 수온 상승 등과 같은 지구온난화현상이 지속되고 있는데 이러한 현상은 이산화탄소, 메탄, 아산화질소 등과 같은 온실가스 배출에 의한 결과로 온실가스 배출 감축에 대한 관심도가 높아지고 있다(Jung et al., 2019; Shim et al., 2019). 이에 온실가스 배출 감축을 위하여 건축, 교통 등 전 분야에 걸쳐 대책이 논의되고 있다. 이 중 2011년 제17차 기후변화 당사국총회에서 목재제품의 탄소저장에 따른 온실가스 저감 효과를 인정함으로써 온실가스 흡수 및 탄소저장 효과를 가진 목재 사용에 대한 관심도가 높아지고 있다(Kim et al., 2019; Chung, 2019; Kim, 2019).

또한 2020년 이후 온실가스 감축이 의무화되면서 세계는 목조건축에 대한 관심도 증가 및 고층 목조 건축물의 시공사례가 증가하고 있다. 목조 건축물은 에너지 사용량 감소 및 온실가스 감축 효과뿐만 아니라 장기적으로 목재를 주요 건축 부재로 사용함으로써 지속가능한 건축기술로 각광받고 있다(Yoo et al., 2019).

이에 목재에 관한 관심도 증가뿐만 아니라 최근 유럽 국가에서 경량목구조 건축물의 단점인 내화방음축열 등을 보완하기 위하여 대형목재패널인 CLT(Cross Laminated Timber: 교차집성판)가 개발 및 사용되고 있다. CLT를 건축부재로 적용 시 프리캐스트 모듈러 공법을 통한 시공기간 단축, 단열 성능 및 기밀성향상과 고층 목조 건축 재료로서 사용가능하다는 장점이 있어 고층 목조건축의 시공사례가 증가하고 있다(Hassanieh et al., 2017; Chang et al., 2018). 시공사례로 2017년 캐나다의 벤쿠버 브리티시 콜롬비아대학 내 18층 목조 건축물, 2009년 영국 런던의 9층 규모의 Stadthaus, 2012년 호주 멜버린의 10층 규모의 Forte 목조 건축물 등이 시공되었다. 영국 런던에서는 초고층 목조건축물인 “오크우드”의 조감도를 공개함으로써 목재를 이용한 고층건축물의 시도가 점차 증가하고 있다(Kim et al., 2019; Kim, 2019).

이처럼 고층 목조건축물에 사용되는 CLT는 층재를 목리방향으로 직교로 적층한 공학목재로 유럽, 미국, 캐나다 등 지역에서 사용되고 있으며 최근 CLT의 구성을 적용한 목질재료 중 LVL, 합판, 대나무보드 등을 혼합 적층한 복합 CLT의 개발 및 성능에 관한 연구가 진행되고 있다(Park et al., 2017; Choi et al., 2015; Choi et al., 2018; Nurdiansyah et al., 2020; Barreto et al., 2019; Wang et al., 2017). 국내에서는 소경목을 이용한 CLT, 난연재료를 이용한 CLT의 재료 특성과 CLT의 전단벽, 접합부 및 주거성능(단열, 흡음)에 대한 연구가 진행되고 있다(Jang et al., 2019; Pang et al., 2017; Choi et al., 2018; Oh et al., 2017; Kang et al., 2019; Jung et al., 2020).

CLT에 관한 활발한 연구뿐만 아니라 국내 CLT 생산 설비가 도입되고 있으며 국산 낙엽송 층재를 이용한 CLT와 수율향상을 위하여 합판을 혼합적층한 Ply-lam CLT가 생산되고 있다(Pang et al., 2019; Choi et al., 2020). 특히 Ply-lam CLT는 국내 생산되는 구조용 낙엽송 합판을 이용하고 있으며, 합판 규격에 따라 길이 $2,440 \mathrm{~mm}$ 의 Ply-lam CLT 제조는 용이하다. 대형목재패 널인 CLT는 $120 \mathrm{~mm}$ 두께의 휨강도 시험편의 길이는 두께의 25-30배인 대략 $3,600 \mathrm{~mm}$ 이상으로 규정되고 있다(ANSI/APA, 2018). 그러나 합판이 혼합 적층되는 Ply-lam CLT는 길이 $2,440 \mathrm{~mm}$ 이상의 패널을 제조할 때 합판의 길이방향 접합이 필수적으 로 요구된다.

본 연구에서는 층재 수종과 길이방향의 합판 접합방식과 접착제 도포 여부에 따른 휨 성능 및 파괴 양상 분석을 통하여 Ply-lam CLT에 적합한 합판 접합 방식을 도출하고자 한다. 


\section{2. 재료 및 방법}

\section{1 공시재료}

\subsection{1 낙엽송 합판}

Ply-lam CLT 제조를 위해 사용된 합판은 낙엽송(Larix kaempferi (Lamb.) Carrière) 원목을 이용하여 인천 소재의 S社로부터 제조된 $15 \mathrm{~mm}$ 의 구조용 낙엽송 합판을 분양받아 사용하였다. 사용된 구조용 낙엽송 합판의 물성은 아래의 Table 1 과 같으며 KS F 3113 구조용 합판 기준 중 1 등급을 통과하는 $15 \mathrm{~mm}$ 두께의 낙엽송 합판을 사용하였다.

\subsection{2 층재}

Ply-lam CLT에 사용된 층재는 더글라스 퍼(Pseudotsuga menziesii(Mirb.) Franco, 전건비중 0.52)과 낙엽송(Larix kaempferi (Lamb., 전건비중 0.54) Carrière)으로 2가지 수종의 층재를 공시재료로 사용하였다. 더글라스 퍼 층재는 기계등급 E12-13(MOE: 12-14 GPa)과 E9(MOE: 9-10 GPa)에 속하는 층재를 분류하였으며 E12-13(MOE: 12-14 GPa)등급은 최외층, E9(MOE: 9-10 GPa) 등급은 중층의 층재로 사용하였다. 낙엽송 층재는 기계등급 E11과 E9에 속하는 층재를 사용하였으며 Ply-lam CLT의 층재 구성은 더글라스 퍼와 동일하게 하였다. 사용된 더글라스 퍼는 무절 층재로 두께 $15 \mathrm{~mm}$, 폭 $100 \mathrm{~mm}$, 길이 $2,400 \mathrm{~mm}$ 규격으로 재단하여 사용하였으며 낙엽송은 유절 층재로 길이방향 핑거결합 방식을 통해 두께 $15 \mathrm{~mm}$, 폭 $100 \mathrm{~mm}$, 길이 $2,400 \mathrm{~mm}$ 규격으로 제조하여 사용하였다.

\subsubsection{Ply-lam CLT 제조}

본 연구에서는 길이방향으로 합판 접합방식 및 접착제 도포 여부에 따른 휨 성능 및 파괴 양상 분석을 통하여 Ply-lam CLT에 적합한 합판 접합 방식을 도출을 위하여 합판 접합이 없는 무처리 조건과 길이방향 접합방식에 따른 3종의 Ply-lam CLT를 제조하였다. 합판의 길이방향 접합방식은 목재의 길이방향 접합을 위해 가장 많이 사용되는 Butt Joint(이하 B.J), Half Lap Joint(이하 H.L), Tongue \& Groove Joint(이하 T.G)의 3가지 접합방식을 선정하였다. 이때 접합방식에 따른 합판의 가공 도면은 Fig. 1과 같다.

합판의 접합방식에 의한 휨 특성 비교를 위하여 합판의 길이방향의 접합부위가 휨강도 시험편의 중앙부에 오도록 배치하여 Ply-lam CLT를 제조하였다.

Ply-lam CLT 제조를 위해 사용된 접착된 접착제는 상온경화형 페놀-레조르시놀 수지를 사용하였으며 주제(페놀-레조르시놀 수지)와 경화제(파라포름알데하이드)를 $100: 30$ 의 비율로 혼합하여 사용하였다. 이때 단면 도포량 $150 \mathrm{~g} / \mathrm{m}^{2}$ 을 기준으로 하였으며 접착제 도포 후 $10 \mathrm{kgf} / \mathrm{cm}^{2}$ 의 압력조건에서 24시간 냉압 후 7일간의 양생을 거쳐 두께 $75 \mathrm{~mm}(5 \mathrm{ply})$ 의 Ply-lam CLT(층재-합판-층 재-합판-층재)를 제조하였다. 조건별로 제조된 Ply-lam CLT는 APA PRG 320 Standard for Performance-Rated Cross-Laminated Timber 및 ASTM D 198-15 Standard Test Methods of Static Tests of Lumber in Structural Sizes에 의거하여 시험편을 재단하였으며 Ply-lam CLT의 제조 조건 및 시험편 크기는 Table 2와 같다.

\section{2 실험방법}

2.2.1 합판 접합 방식에 따른 Ply-lam CLT의 휨 성능 평가 및 파괴양상 분석

제조된 휨 성능 시험편 $(75 \mathrm{~mm}(\mathrm{~T}) \times 305 \mathrm{~mm}(\mathrm{~W}) \times 2,400 \mathrm{~mm}(\mathrm{~L}))$ 은 만능재료시험기(KDPI-130-1)를 이용하여 ASTM D 198-15 휨 성능 평가 방법 중 Two-Point Loading으로 시험을 하였다. 이때 시험편의 span은 $2,175 \mathrm{~mm}$ (두께의 29 배)로 하중속도는 약 300 초 이내에 최대하중에 도달하도록 설정하였다. 최대하중으로 휨강도(Modulus of Rupture)와 시험편의 중앙부에서 측정한 처짐과 하중으로 휨탄성계수(Modulus of Elasticity)를 식(1)과 식(2)에 의거하여 산출하였다.

$$
\text { Modulus of Rupture }(M P a)=\frac{3 P_{\max } a}{b d^{2}} \cdots \cdots . . .(\text { e.q. } 1)
$$

$P_{\text {max: }}$ maximum load borne by specimen loaded $(N)$

a: distance from reaction to nearest load point $(\mathrm{mm})$

b: width of specimen $(\mathrm{mm})$

$d$ : depth of specimen ( $\mathrm{mm}$ ) 
Gyu Woong CHOI $\cdot$ Seung Min YANG $\cdot$ Hyun Jae LEE $\cdot$ Jun Ho KIM $\cdot$ Kwang Hyeon CHOI $\cdot$ Seog Goo KANG$$
\text { Modulus of Elasticity }(G P a)=\frac{P a}{4 b d^{3} \triangle}\left(3 l^{2}-4 a^{2}\right) \cdots \cdots \cdots(\text { e.q. } 2)
$$ \\ $P$ : increment of applied load on flexure specimen below proportional limit $(N)$ \\ a: distance from reaction to nearest load point ( $\mathrm{mm}$ ) \\ $b$ : width of specimen $(\mathrm{mm})$ \\ $d$ : depth of specimen (mm) \\ l: span of beam (mm) \\ $\triangle$ : increment of deflection of neutral axis of flexure specimen measured at midspan over distance and corresponding load (mm)
}

산출된 결과는 SPSS(ver. 24.0, SPSS Inc., USA)를 이용하여 일원배치 분산분석(One-way ANOVA)을 실시하였으며 평균값 의 유의성 $(\mathrm{P}<0.05)$ 은 Duncan's multiple range test로 검정하였다.

\title{
3. 결과 및 고찰
}

3.1 층재 수종에 따른 Ply-lam CLT의 휨성능 비교

3.1.1 더글라스 퍼 층재를 이용한 Ply-lam CLT

더글라스 퍼 층재를 사용한 Ply-lam의 휨 성능 결과는 Fig 2 와 같다. 길이방향 접착제 도포 여부에 따라서 무처리 조건과 butt joint의 경우 동일 수준의 강도 값을 나타냈으며, 평균값 기준 접착제 미도포한 경우 half lap, tongue \& groove에서 약 $10 \%$ 의 휨강도 감소를 나타냈으며, 접착제 도포한 경우 tongue \& groove에서 약 $7 \%$ 의 휨강도 감소를 나타냈다. 접착제 도포여부 와 상관없이 길이방향 접합방식에 의하여 약 $11.5 \%$ 의 휨탄성계수가 감소하였다.

합판의 길이방향 접합이 없는 무처리 조건과 길이방향 접합 방식 3종의 휨강도와 휨탄성계수의 평균 유의성을 검증하였다 (Table 3). 접착제를 도포하지 않은 경우 무처리 조건과 접합방식에 따른 휨강도 결과는 유의한 차이를 나타내지 않았고, 접착제 를 도포한 조건에서 유의한 차이를 나타냈다.

또한 접착제 도포여부에 따라 휨강도 $(\mathrm{F}=2993, \mathrm{p}=0.031)$ 는 유의한 차이를 나타냈으며 접착제 도포 조건이 더 높은 수준의 강도 값을 나타냈으나 휨탄성계수 $(\mathrm{F}=0.739, \mathrm{p}=0.602)$ 는 접착제 도포여부에 따른 유의한 차이를 나타내지 않았다. 접착제를 도포한 경우 half lap joint 접합방식, 접착제 미도포의 경우 butt joint가 가장 높은 휨강도 성능을 나타냈다.

\subsection{2 낙엽송 층재를 이용한 Ply-lam CLT}

낙엽송 층재를 사용한 Ply-lam의 휨 성능 결과는 Fig. 3 와 같다. 합판의 길이방향 접합이 없는 무처리 조건과 길이방향 접합 방식 3 종의 휨강도와 휨탄성계수의 평균 유의성 검증 결과 유의한 차이를 나타냈다. 길이방향 접합 여부에 따라서 휨강도는 약 $15 \%$ 감소, 휨탄성계수는 약 $40 \%$ 감소하는 결과를 나타냈다.

접합 방식에 따른 휨강도와 휨탄성계수의 유의성 검증 결과 접합방식에 관계없이 유의한 차이를 나타내지 않았다. 또한 접착제 도포여부에 따른 휨강도 $(\mathrm{F}=0.059, \mathrm{p}=0.997)$ 와 휨탄성계수 $(\mathrm{F}=0.364, \mathrm{p}=0.868)$ 도 유의한 차이를 나타내지 않았다.

\section{2 접착제 도포여부에 따른 휨 파괴 양상}

길이방향 접합이 없는 무처리 조건은 최대하중에서 옹이와 같은 결함에서 파괴가 시작되며 $2 \mathrm{ply}$ 합판 단판의 레이어별로 파괴가 발생한다. 반면 합판 접합부위 접착제 도포된 경우 butt joint는 다른 접합 방식과는 다르게 최외층재(outermost lamina layer)가 파괴될 경우 중층의 합판 접합부(plywood joint)를 통과하여 코어부의 층재로 바로 파괴가 전달되는 것으로 나타났다 (Table 5). 그러나 half lap joint, tongue \& groove joint에서는 중층 합판에서 바로 코어부의 층재로 파괴가 전달되지 않고 합판에서 우선 파괴가 발생하였다. 이로 인해 코어부로의 파괴가 바로 전달되는 것을 완화시켜주는 것으로 판단하였다. 라디에타 파인 층재를 사용한 경우 접착제를 도포한 half lap joint, butt joint에서 강도 향상의 효과는 나타냈으나 tongue \& groove joint는 합판이 먼저 파괴되어 휨 강도가 개선되지는 않았다.

접착제를 도포하지 않은 경우의 파괴 양상 또한 접착제를 도포한 경우의 파괴양상과 동일한 결과를 나타내는 것으로 분석되었 다(Table 6). 


\section{4. 결론}

본 연구에서는 Ply-lam CLT의 합판 접합 방식에 따른 휨 성능 평가를 위하여 층재 2종(낙엽송, 더글라스 퍼), 합판의 접합 방식 3종(butt joint, half lap joint, tongue groove joint), 중층 합판 접착 간의 접착제 도포 유무에 따른 강도성능을 비교분석하였 으며, 다음과 같은 결과를 도출하였다.

1. 더글라스 퍼 층재의 경우 합판 접합에 의해 무절조건(condition without plywood joint) 대비 휨탄성계수 약 $11.5 \%$ 감소, 휨강도는 접착제 도포 및 접합방식에 따라 증가 또는 감소하였다. 접착제 미도포 butt joint, 접착제 도포 half lap joint, butt joint 조건이 최적조건으로 도출 되었다.

2. 낙엽송 층재의 경우 길이방향 접합에 의해 휨강도는 약 $15 \%$, 휨탄성계수는 약 $40 \%$ 감소하였으며 접합방식에 따른 차이를 나타내지 않았다.

3. half lab joint와 tongue \& groove joint 사용 시 합판 층의 접합부에서 휨에 파괴를 1차적으로 방지해줌으로써 중층의 층재로 전달되는 하중을 감소시켜주는 것으로 판단된다.

4. 본 연구 결과를 통해 Ply-lam CLT 제조과정에서 낙엽송 층재를 사용하는 경우 접합방법에 따른 차이를 나타내지 않았으며 더글라스퍼 층재를 사용할 경우 butt joint와 half lap 접합 방식이 적합할 것으로 판단된다. 